\title{
Advances in the management of diabetes: therapies for type 2 diabetes
}

\author{
Jovanna Tsoutsouki, Wunna Wunna, Aisha Chowdhury, Tahseen Ahmad Chowdhury
}

Department of Diabetes, Royal London Hospital, London, UK

\section{Correspondence to} Professor Tahseen Ahmad Chowdhury, Dept of Diabetes, Royal London Hospital, London, UK;

tahseen.chowdhury@nhs.net

Received 17 March 2020 Revised 28 April 2020 Accepted 29 April 2020
Check for updates

(c) Author(s) (or their employer(s)) 2020. No commercial re-use. See rights and permissions. Published by BMJ.

To cite: Tsoutsouki J, Wunna W, Chowdhury A, et al. Postgrad Med 2020:96:610-618.

\section{ABSTRACT}

The incidence of type 2 diabetes is rapidly rising worldwide leading to an increasing burden of cardiovascular and microvascular complications. The aim of treatment of the condition is to improve quality of life and reduce such complications. To this end, improvement in glucose control remains an important consideration. In recent years, important therapeutic advances have occurred in the management of hyperglycaemia in people with type 2 diabetes. These include the use of dipeptidylpeptidase-4 inhibitors, glucagon-like peptide-1 receptor agonists and sodium glucose transporter-2 inhibitors. The latter two classes appear to have some specific beneficial effects on cardiovascular and renal outcomes, independent of their antihyperglycaemic effects. This review aims to outline the current state of diagnosis and management of diabetes for the general physician, with a particular focus on new therapeutic agents for management of glucose in patients with type 2 diabetes.

\section{INTRODUCTION}

In 2017, it was estimated that 451 million adults worldwide had diabetes, equivalent to around 1 adult in 11 living with the condition, ${ }^{1}$ and approximately $90 \%$ of these patients have type 2 diabetes (T2D). ${ }^{2}$ Alarmingly, at present rate of increase, this number is expected to rise to 693 million by 2045 . Around 5 million deaths worldwide were linked to diabetes in 2017, and the global healthcare expenditure on the condition was estimated to be US $\$ 850$ billion. $^{2}$

In high-income countries, diabetes is the most common cause of blindness in people of working age ${ }^{3}$ the most common cause of end-stage kidney disease (ESKD) and non-traumatic amputation. ${ }^{4}$ Cardiovascular (CV) complications are, however, the leading cause of morbidity and mortality, with nearly three out of every four people with the condition dying from $\mathrm{CV}$ complications. ${ }^{2}$ Furthermore, the risk of a stroke is increased by four times, ${ }^{5}$ development of liver cirrhosis by three times ${ }^{6}$ and epidemiological data also suggest a significantly increased risk of cancer in patients with diabetes, independent of obesity. ${ }^{7}$ It is also increasingly recognised that heart failure is a major diabetes-related comorbidity. ${ }^{8}$

Multiple factors have driven the global epidemic of T2D, including ageing populations, sedentary lifestyles, obesity and unhealthy diets. ${ }^{2}$ T2D may be preventable with lifestyle change. Meta-analysis suggests a role for lifestyle intervention and/or metformin in preventing the onset of T2M in patients with non-diabetic hyperglycaemia. ${ }^{9}$

\section{Diagnosis of diabetes}

Diagnosis of diabetes is based on biochemical evidence of hyperglycaemia, in the presence or absence of symptoms. ${ }^{10}$ Symptoms include polyuria, polydipsia, unexplained weight loss, hyperphagia, recurrent orogenital candidiasis or skin abscesses. Diagnostic criteria for diabetes are shown in table 1 . In patients who do not have symptoms, at least one additional measurement in the diabetes range is required.

WHO suggests that the use of glycated haemoglobin $\left(\mathrm{HbA}_{1 \mathrm{C}}\right)$ in the diagnosis of $\mathrm{T} 2 \mathrm{D}$ provides a convenient screening method (table 1). ${ }^{11}$ It is important to note, however, that the value of $\mathrm{HbA}_{1 \mathrm{C}}$ is dependent on the lifespan of red blood cells. Therefore, any condition that might increase red cell turnover (such as haemolysis or blood loss) will lead to a falsely lowered $\mathrm{HbA}_{1 \mathrm{c}}$, and any condition that reduces red cell turnover (such as severe iron deficiency) can lead to a falsely elevated $\mathrm{HbA}_{1 \mathrm{c}}{ }^{12}$ In addition, haemoglobinopathy or interfering haemoglobins may render the $\mathrm{HbA}_{1 \mathrm{c}}$ uninterpretable, and hence glucose tests should be used diagnostically in this circumstance.

\section{Glycaemic control in T2D}

The aim of management of diabetes is to improve quality of life and reduce diabetes-related symptoms and complications. Interventions to reduce complications include diabetes education to aid selfmanagement, smoking cessation, improved diet and exercise, and management of blood pressure and lipids. ${ }^{13}$ In addition, systematic annual screening for complications is required. Table 2 lists the regular assessments and interventions which people with diabetes require each year.

There exists an array of conflicting evidence demonstrating the effects of intensive versus standard glycaemic control on diabetes outcomes. A meta-analysis studying 13 randomised controlled trials (RCTs) favoured intensive glucose control at reducing risk of non-fatal myocardial infarction (MI), but showed no significant effect on CV death and all-cause mortality when compared with standard glucose control. ${ }^{14}$ This was, however, associated with a doubling in risk of severe hypoglycaemia as well as significant weight gain. With regards to microvascular complications, the meta-analysis only demonstrated a significant $10 \%$ reduction in the risk of microalbuminuria. There exists nevertheless stronger evidence that intensive glucose control may reduce the risk of nephropathy (microalbuminuria and macroalbuminuria) and progressive retinopathy in T2D. This does not, however, translate to conclusive evidence that 
Table 1 Diagnostic criteria for diabetes mellitus and abnormal glucose tolerance

\begin{tabular}{|c|c|c|c|c|c|}
\hline & $\begin{array}{l}\text { Fasting plasma } \\
\text { glucose (mmol/L) }\end{array}$ & & $\begin{array}{l}2 \text { hours plasma } \\
\text { glucose ( } \mathrm{mmol} / \mathrm{L})\end{array}$ & Random plasma glucose (mmol/L) & Glycated haemoglobin (\%) \\
\hline Normal & $\leq 6.0$ & - & $<7.8$ & $<7.8$ & $\begin{array}{l}<6.0 \\
(<42 \mathrm{mmol} / \mathrm{mol})\end{array}$ \\
\hline Impaired fasting glucose & $6.1-6.9$ & and & $<7.8$ & - & - \\
\hline Impaired glucose tolerance & $<7.0$ & and & $7.8-11.0$ & - & $\begin{array}{l}\text { Pre-diabetes: } \\
6.0-6.4 \\
(42-47 \mathrm{mmol} / \mathrm{mol})\end{array}$ \\
\hline Diabetes mellitus & $\geq 7.0$ & or & $\geq 11.1$ & $\geq 11.1$ & $\begin{array}{l}>6.5 \\
(>48 \mathrm{mmol} / \mathrm{mol})\end{array}$ \\
\hline
\end{tabular}

intensive glucose lowering treatment reduces the risk of ESKD, blindness or amputation in patients with T2D. ${ }^{15}$ Meta-analysis of observational studies also suggests a 'J-shaped' relationship between $\mathrm{HbA}_{1 \mathrm{c}}$ and all-cause mortality in patients with $\mathrm{T} 2 \mathrm{D}$, whereby very low $\mathrm{HbA}_{1 \mathrm{c}}$ levels appear to be associated with an increased risk of all-cause mortality. ${ }^{16}$

The Action to Control Cardiovascular Risk in Diabetes (ACCORD) study was an RCT specifically designed to look at the effect of intensive glycaemic control $\left(\mathrm{HbA}_{1 \mathrm{c}}<6 \%\right.$ vs $7 \%-$ $7.9 \%$ ) on macrovascular (cardiovascular disease (CVD) morbidity, all-cause mortality) and microvascular complications in patients with T2D. ${ }^{17}$ The intensive glycaemic control arm had to be prematurely discontinued after a median of 3.7 years follow-up due to concerning evidence that it led to a $22 \%$ increase in all-cause mortality rate (HR 1.22, CI 1.01 to 1.46 , $p=0.04)$. The ACCORD trial did have its limitations as all the participants belonged to a higher risk group with average diabetes duration of about 10 years, and were either older or with already established or high-risk CVD, compared with previous studies. Also, the tailoring of medication in order to achieve the target $\mathrm{HbA}_{1 \mathrm{c}}$ was not carefully selected, leading to high rates of hypoglycaemia which might have contributed to these higher mortality rates.

With this in mind, many international guidelines suggest individualisation of glycaemic targets. The 2018 European Association for the Study of Diabetes and the American Diabetes Association guidelines currently suggest an $\mathrm{HbA}_{1 \mathrm{c}}$ target

Table 2 Annual assessment and interventions in patients with type 2 diabetes

\begin{tabular}{|c|c|}
\hline Assessment & Intervention \\
\hline Diet and lifestyle & $\begin{array}{l}\text { Referral for structured diabetes education } \\
\text { and dietary management }\end{array}$ \\
\hline Smoking status & Referral for smoking cessation \\
\hline Foot assessment & $\begin{array}{l}\text { If high risk for ulceration, referral for } \\
\text { podiatry }\end{array}$ \\
\hline Digital retinal screen & $\begin{array}{l}\text { Referral for retinopathy management to } \\
\text { ophthalmology }\end{array}$ \\
\hline Blood pressure (BP) & $\begin{array}{l}\text { Treat if persistently above } 140 / 80 \mathrm{~mm} \mathrm{Hg} \text { (or } \\
130 / 80 \mathrm{~mm} \mathrm{Hg} \text { with renal or cardiovascular } \\
\text { disease) }\end{array}$ \\
\hline Lipids & $\begin{array}{l}\text { Statin therapy in all with CHD risk }>10 \% \text {, or } \\
\text { type } 1 \text { diabetes }>10 \text { years }\end{array}$ \\
\hline $\begin{array}{l}\text { Renal assessment (urine albumin/ } \\
\text { creatinine ratio (ACR) and estimated } \\
\text { GFR) }\end{array}$ & $\begin{array}{l}\text { ACE inhibitors or angiotensin receptor } \\
\text { blockers if ACR elevated, aiming for BP } \\
<130 / 80 \mathrm{~mm} \mathrm{Hg}\end{array}$ \\
\hline Glycaemic control $\left(\mathrm{HbA}_{1 \mathrm{c}}\right)$ & Decide on target and optimise therapy \\
\hline
\end{tabular}

GFR, glomerular filtration rate. of around $53 \mathrm{mmol} / \mathrm{mol}(7.0 \%)$ or less, but individualised based on patient characteristics and risk of adverse effects of therapy. ${ }^{18}$ Similarly, the UK National Institute of Health and Clinical Excellence guidelines recommend that $\mathrm{HbA}_{1 \mathrm{c}}$ targets should be relaxed in patients who are at high risk of the consequences of hypoglycaemia, such as the older, frailer and those with a longer duration of diabetes, or presence of severe comorbidities and/or established vascular complications. ${ }^{19} 20$

\section{PHARMACOLOGICAL MANAGEMENT OF GLUCOSE IN T2D}

The number of therapeutic agents available for the management of hyperglycaemia in T2D has grown significantly in the last two decades. In 2008, the US Food and Drug Advisory Committee mandated that all new antihyperglycaemic therapies should undergo testing to establish their CV safety, using cardiovascular outcome trials (CVOTs). ${ }^{21}$ This was in response to concerns around the use of rosiglitazone which, while an effective antihyperglycaemic agent, appeared to increase $\mathrm{CV}$ events in certain patients. ${ }^{22}$ CVOTs are large, multicentre, double-blind, randomised control trials, most of which use three-point major adverse cardiovascular events (3p-MACE) as their primary endpoint (non-fatal stroke, nonfatal MI and CV death), with some also adding hospitalisation for unstable angina to these three outcomes (4p-MACE). Hospitalisation for heart failure ( $\mathrm{hHf}$ ), being a common complication of T2D and contributing to its high mortality, is also included, usually as a secondary end point. More recently, there has been a shift of focus of trials specifically examining renal outcomes.

Table 3 presents an overview of newer and older glucose lowering medications, and table 4 outlines the latest CVOTs published using newer glucose lowering medications.

\section{Older agents}

\section{Metformin}

Metformin is the first line antihyperglycaemic for the management of T2D in the absence of contraindications. ${ }^{23}$ It inhibits gluconeogenesis and increases insulin-mediated glucose utilisation peripherally. ${ }^{24}$ It has good glycaemic efficacy $(10-15 \mathrm{mmol} /$ mol (1.0\%-1.5\%) $\mathrm{HbA}_{1 \mathrm{c}}$ reduction) and excellent long-term safety profile. ${ }^{25}$ It does not cause hypoglycaemia and favours weight reduction (approximately $1.1 \mathrm{~kg}$ ). ${ }^{26}$ The most common side effect is gastrointestinal upset, which may be mitigated by slow titration and taking the drug with meals. ${ }^{27}$ It is contraindicated in patients with estimated glomerular filtration rate (eGFR) $<30 \mathrm{~mL} / \mathrm{min} / 1.73 \mathrm{~m}^{2}$, active liver disease, unstable heart failure or history of lactic acidosis while on metformin. There is weak evidence associating metformin use in these subgroups to lactic acidosis. $^{28}$ 
Table 3 An overview of antidiabetic medications

\begin{tabular}{|c|c|c|c|c|}
\hline Class & Mechanism of action & Clinical characteristics & Side effects & Contraindications/cautions \\
\hline $\begin{array}{l}\text { Biguanide: } \\
\text { Metformin }\end{array}$ & $\begin{array}{l}\text { Decrease hepatic gluconeogenesis } \\
\text { and intestinal glucose absorption } \\
\text { Increase insulin-mediated glucose } \\
\text { utilisation peripherally }\end{array}$ & $\begin{array}{l}\text { Reduce LDL/increase HDL } \\
\text { cholesterol } \\
\text { Low risk of hypoglycaemic } \\
\text { Weight neutral } \\
\text { Cost effective }\end{array}$ & $\begin{array}{l}\text { Gastrointestinal symptoms } \\
\text { (nausea, diarrhoea, flatulence) } \\
\text { Metformin-associated lactic } \\
\text { acidosis (rare) }\end{array}$ & $\begin{array}{l}\text { Chronic kidney disease (CKD; eGFR } \\
<30 \mathrm{~mL} / \mathrm{min} \text { ) } \\
\text { Severe liver failure } \\
\text { Previous lactic acidosis on } \\
\text { metformin }\end{array}$ \\
\hline $\begin{array}{l}\text { Sulfonylureas: } \\
\text { Gliclazide } \\
\text { Prandial glucose regulators: } \\
\text { Repaglinide }\end{array}$ & Increase insulin secretion by beta-cells & Low cost & $\begin{array}{l}\text { Hypoglycaemic } \\
\text { Weight gain }\end{array}$ & $\begin{array}{l}\text { Obesity } \\
\text { Severe cardiovascular comorbidity }\end{array}$ \\
\hline $\begin{array}{l}\text { Thiazolidinediones: } \\
\text { Pioglitazone }\end{array}$ & $\begin{array}{l}\text { Increase insulin sensitivity by } \\
\text { activating PPAR } r\end{array}$ & $\begin{array}{l}\text { Reduce } L D L \text { and triglycerides } \\
\text { Increase HDL } \\
\text { No risk of hypoglycaemia }\end{array}$ & $\begin{array}{l}\text { Fluid retention } \\
\text { Weight gain } \\
\text { Increased risk of heart failure } \\
\text { Postmenopausal fracture }\end{array}$ & $\begin{array}{l}\text { Congestive heart failure } \\
\text { Liver failure } \\
\text { History of bladder cancer } \\
\text { Osteopaenia/osteoporosis }\end{array}$ \\
\hline $\begin{array}{l}\text { GLP-1 RA: } \\
\text { Albiglutide } \\
\text { Dulaglutide } \\
\text { Exenatide } \\
\text { Liraglutide } \\
\text { Semaglutide }\end{array}$ & $\begin{array}{l}\text { Mimic incretin effect: increase insulin } \\
\text { secretion, decrease glucagon } \\
\text { secretion, delay gastric emptying }\end{array}$ & $\begin{array}{l}\text { No risk of hypoglycaemia } \\
\text { Weight loss }\end{array}$ & $\begin{array}{l}\text { Gastrointestinal upset } \\
\text { Association with pancreatitis }\end{array}$ & $\begin{array}{l}\text { Chronic pancreatitis or family } \\
\text { history of pancreatic cancer }\end{array}$ \\
\hline $\begin{array}{l}\text { DPP-4i: } \\
\text { Alogliptin } \\
\text { Linagliptin } \\
\text { Saxagliptin } \\
\text { Sitagliptin } \\
\text { Vildagliptin }\end{array}$ & $\begin{array}{l}\text { Increase endogenous insulin and } \\
\text { suppress glucagon. }\end{array}$ & $\begin{array}{l}\text { No risk of hypoglycaemia } \\
\text { Weight neutrality }\end{array}$ & $\begin{array}{l}\text { Gastrointestinal upset } \\
\text { Slight increased risk of } \\
\text { pancreatitis }\end{array}$ & Personal history of pancreatitis \\
\hline $\begin{array}{l}\text { SGLT-2i: } \\
\text { Canaglifozin Dapaglifozin } \\
\text { Empaglifozin }\end{array}$ & $\begin{array}{l}\text { Reversible inhibition of SGLT2 } \\
\text { receptors in the kidney leading to } \\
\text { glycosuria and reduced glucose } \\
\text { absorption }\end{array}$ & $\begin{array}{l}\text { Weight loss } \\
\text { Reduces blood pressure } \\
\text { Cardiovascular and renal } \\
\text { protection }\end{array}$ & $\begin{array}{l}\text { Urogenital infections } \\
\text { Euglycaemic diabetic ketoacidosis } \\
\text { Fournier's gangrene (rare) }\end{array}$ & $\begin{array}{l}\text { Recurrent urinary tract infections } \\
\text { CKD }\end{array}$ \\
\hline
\end{tabular}

DPP-4i, dipeptidylpeptidase-4 inhibitor; eGFR, estimated glomerular filtration rate; GLP-1 RA, glucagon-like peptide-1 receptor agonist; HDL, high-density lipoprotein; LDL, low-density lipoprotein; PPARg, perioxisome proliferator activated receptor-g; SGLT-2i, sodium glucose transporter-2 inhibitor.

Metformin reduces all-cause mortality and hHF. ${ }^{29}$ There is some epidemiological evidence that it may reduce the risk of cancer. 3031

\section{Sulfonylureas}

Sulfonylureas stimulate pancreatic beta-cells to release insulin. Their use is favoured by their low cost and potent glucoselowering properties (10-15 mmol/mol (1\%-1.5\%) $\mathrm{HbA}_{1 \mathrm{c}}$ reduction). ${ }^{32}$ Weight gain associated with their use is a significant undesired risk factor, and sulfonylureas may also lose efficacy as a result of beta-cell failure. ${ }^{33}$ Hypoglycaemia, which can be severe in certain groups such as the elderly or renally impaired, is the main factor limiting their use, as it is much more frequent compared with incretin-based therapies or metformin. ${ }^{34} 35$ As sulfonylurea metabolites are renally excreted, the risk of hypoglycaemia is significantly higher in patients with chronic kidney disease (CKD), although less problematic with shorter acting sulfonylureas with mostly inactive metabolites, such as glimepiride and gliclazide. ${ }^{36}$ Sulfonylureas may cause severe, prolonged hypoglycaemia, especially in the elderly with the presence of cognitive decline or meal inconsistency. ${ }^{37}$ Newer sulfonylureas may have a slightly more favourable CV profile, compared with older agents. ${ }^{38}$

\section{Thiazolidinediones}

Thiazolidinediones (glitazones) act via perioxisome proliferatoractivated receptor- $\gamma$ receptors in muscle, adipose tissue and liver to increase insulin sensitivity. They have similar glycaemic effectiveness to metformin, ${ }^{39}$ but their use is limited due to adverse effects, including weight gain and fluid retention, which can exacerbate heart failure (and hence are contraindicated), ${ }^{40}$ and increased postmenopausal fractures in women. ${ }^{41}$ An increased risk of bladder cancer was associated with pioglitazone use in $\mathrm{T} 2 \mathrm{D},{ }^{42}$ although this association was not confirmed at 10 -year follow-up. ${ }^{43}$

Rosiglitazone increases baseline LDL levels, ${ }^{44}$ and was associated with a $43 \%$ increase in MI in a meta-analysis, ${ }^{25}$ although this was not confirmed in a subsequent RCT. ${ }^{45}$ Rosiglitazone has been discontinued in Europe following concerns over its safety profile.

\section{Newer agents}

Glucagon-like peptide-1 receptor analogues (GLP-1 RA)

GLP-1, a natural peptide involved in glucose homeostasis, is secreted by the L-cells of the small intestine in response to glucose ingestion. It stimulates pancreatic $\beta$-cell insulin secretion, inhibits glucagon release from $\alpha$-cells and has a direct effect on delaying gastric emptying and inducing satiety. ${ }^{46}$ This is known as the incretin effect, which is disrupted in T2D. ${ }^{47}$ Native GLP-1 has a short half-life as it is degraded by the enzyme, dipeptidylpeptidase-4 (DPP-4). ${ }^{48}$

GLP1-RAs stimulate glucose-dependent insulin secretion. They are resistant to DPP-4 degradation and are administered subcutaneously. They achieve significant reductions in $\mathrm{HbA}_{1 \mathrm{c}}$ without the risk of hypoglycaemia. GLP1-RAs favour weight loss and improvements in lipids and blood pressure. They can be initiated in patients with eGFR as low as $15 \mathrm{~mL} / \mathrm{min} / 1.73 \mathrm{~m}^{2}$.

Gastrointestinal upset is a common adverse effect, and frequent reason for discontinuation. Early studies suggested an association with pancreatitis and pancreatic cancer, but this unconfirmed in recent meta-analysis. ${ }^{49}$ In SUSTAIN-6, semaglutide was linked to higher rates of retinopathy compared with 
Table 4 A summary of cardiovascular (CV) outcomes trials with antihyperglycaemic medications in type 2 diabetes (T2DM)

\begin{tabular}{|c|c|c|c|c|c|}
\hline Class & Drug & $\begin{array}{l}\text { CVOT and total } \\
\text { patients }(\mathrm{n})\end{array}$ & $\begin{array}{l}\text { Median } \\
\text { follow-up } \\
\text { (years) }\end{array}$ & Patient characteristics (all T2DM) & Outcomes \\
\hline \multirow[t]{4}{*}{ SGLT-2i } & Empagliflozin & $\begin{array}{l}\text { EMPA-REG Outcome } \\
(2015) \\
\mathrm{n}=7020\end{array}$ & 3.1 & $\begin{array}{l}\text { Established CVD (99\%) eGFR >30 } \\
\text { History of: } \\
\text { Ml>50\% } \\
\text { Multivessel CVD } 5 \% \\
\text { HF } 10 \%\end{array}$ & $\begin{array}{l}\text { Lower 3p-MACE HR } 0.86 \text { ( } 0.79 \text { to } 0.9 \text { ) } \\
\text { Lower CV-related deaths HR } 0.62 \text { (0.49 to } 0.77) \\
\text { Lower death from any cause HR } 0.68 \text { ( } 0.57 \text { to } 0.82 \text { ) } \\
\text { Lower hHF HR } 0.65 \text { ( } 0.50 \text { to } 0.85 \text { ) } \\
\text { No significant difference in: Ml, stroke }\end{array}$ \\
\hline & \multirow[t]{2}{*}{ Canagliflozin } & $\begin{array}{l}\text { CANVAS Program } \\
(2017) \\
\mathrm{n}=10142\end{array}$ & 2.4 & $\begin{array}{l}\text { Either: } \\
\text { 1. }>30 \text { years old +established } \\
\text { CVD }(65.6 \%) \\
\text { 2. }>50 \text { years }+2 \text { or more } \mathrm{CV} \text { risk } \\
\text { factors eGFR }>30\end{array}$ & $\begin{array}{l}\text { Lower 3p-MACE HR } 0.86 \text { ( } 0.75 \text { to } 0.97 \text { ) } \\
\text { Lower albuminuria progression HR } 0.73 \text { ( } 0.67 \text { to } 0.79 \text { ) } \\
\text { Lower composite outcome of } 40 \% \text { eGFR reduction, RRT need, death } \\
\text { from renal causes } \\
\text { HR } 0.60 \text { ( } 0.47 \text { to } 0.77 \text { ) } \\
\text { No significant difference in CV death, death from any cause }\end{array}$ \\
\hline & & $\begin{array}{l}\text { CREDENCE } \\
(2019) \\
\mathrm{n}=4401\end{array}$ & 2.62 & Albuminuric CKD & $\begin{array}{l}\text { Lower renal-specific composite of ESRD, doubling of creatinine, } \\
\text { death from renal causes } \\
\text { HR } 0.66 \text { ( } 0.53 \text { to } 0.81) \\
\text { Lower ESRD HR } 0.68 \text { ( } 0.54 \text { to } 0.86) \\
\text { Lower CV death, MI, stroke HR } 0.80 \text { ( } 0.67 \text { to } 0.95 \text { ) } \\
\text { Lower hHF HR } 0.61 \text { ( } 0.47 \text { to } 0.80)\end{array}$ \\
\hline & Dapagliflozin & $\begin{array}{l}\text { DECLARE-TIMI } 58 \\
(2019) \\
\mathrm{n}=17160\end{array}$ & 4.2 & $\begin{array}{l}\text { Either: } \\
\text { 1. Established CVD }(40.6 \%) \\
\text { 2. Multiple CV risk factors } \\
(59.4 \%)\end{array}$ & $\begin{array}{l}\text { No significant difference in } 3 \mathrm{p}-\mathrm{MACE} \\
\text { HR } 0.93 \text { ( } 0.84 \text { to } 1.03) \\
\text { Lower hHF HR } 0.73 \text { ( } 0.61 \text { to } 0.88) \\
\text { Reduced renal events HR } 0.76 \text { ( } 0.67 \text { to } 0.87 \text { ) } \\
\text { No significant difference in CV death, death from any cause }\end{array}$ \\
\hline \multirow[t]{5}{*}{ DPP-4i } & Saxagliptin & $\begin{array}{l}\text { SAVOR-TIMI } 53 \\
(2013) \\
n=16492\end{array}$ & 2.1 & History or multiple risk factors for CVD & $\begin{array}{l}\text { No significant difference in 3p-MACE } \\
\text { HR } 1.0 \text { ( } 0.89 \text { to } 1.12 \text { ) } \\
\text { No significant difference in all-cause mortality, CV death, MI, stroke, } \\
\text { hospitalisation for angina } \\
\text { Significant increase in hHF HR } 1.27 \text { (1.07 to } 1.51)\end{array}$ \\
\hline & Alogliptin & $\begin{array}{l}\text { EXAMINE } \\
(2013) \\
\mathrm{n}=5380\end{array}$ & 1.5 & $\begin{array}{l}\text { ACS (AMI or UA requiring } \\
\text { hospitalisation) within } 15-90 \text { days } \\
\text { before randomisation }\end{array}$ & $\begin{array}{l}\text { No significant difference in 3p-MACE HR } 0.96 \text { ( } \leq 1.16 \text { ) } \\
\text { No significant difference in all-cause mortality, CV death } \\
\text { Contributed to a non-significant 19\% increase in hHF }\end{array}$ \\
\hline & Sitagliptin & $\begin{array}{l}\text { TECOS } \\
(2015) \\
\mathrm{n}=14671\end{array}$ & 3.0 & Established CVD & $\begin{array}{l}\text { No significant difference in } 4 \text { p-MACE } \\
\text { HR } 0.98 \text { ( } 0.88 \text { to } 1.09 \text { ) } \\
\text { No significant difference in hHF HR } 1.0 \text { ( } 0.83 \text { to } 1.20)\end{array}$ \\
\hline & \multirow[t]{2}{*}{ Linagliptin } & $\begin{array}{l}\text { CARMELINA } \\
(2018) \\
\mathrm{n}=6979\end{array}$ & 2.2 & $\begin{array}{l}\text { High CV risk (history of vascular disease } \\
\text { and UACR }>200 \mathrm{mg} / \mathrm{g} \text { ), and } \\
\text { High renal risk (reduced eGFR and } \\
\text { microalbuminuria or macroalbuminuria). } \\
\text { ESRD patients excluded }\end{array}$ & $\begin{array}{l}\text { No significant difference in 3p-MACE } \\
\text { HR } 1.02 \text { (0.89 to } 1.17 \text { ) } \\
\text { No significant difference for hHF HR } 0.90 \text { (0.74 to } 1.08 \text { ) }\end{array}$ \\
\hline & & $\begin{array}{l}\text { CAROLINA } \\
(2019) \\
\mathrm{n}=6042\end{array}$ & 6.3 & High CV risk & $\begin{array}{l}\text { Non inferior to glimepiride in } 3 p-M A C E \\
\text { HR } 0.98 \text { ( } 0.84 \text { to } 1.14) ; p<0.001 \text { for non-inferiority }\end{array}$ \\
\hline \multirow[t]{6}{*}{ GLP-1 RA } & Exenatide & $\begin{array}{l}\text { EXSCEL (2017) } \\
n=14752\end{array}$ & 3.2 & 73.1\% with established CVD & $\begin{array}{l}\text { No significant difference in 3p-MACE HR } 0.91 \text { ( } 0.83 \text { to } 1.00 \text { ) } \\
\text { No significant difference in CV death, fatal or non-fatal MI, fatal or } \\
\text { non-fatal stroke, hHF, ACS hospitalisation }\end{array}$ \\
\hline & Lixisenatide & $\begin{array}{l}\text { ELIXA } \\
(2015) \\
n=6068\end{array}$ & 2.1 & History of ACS & $\begin{array}{l}\text { No significant difference in 4P-MACE HR } 1.02(95 \% \mathrm{Cl} 0.89 \text { to } 1.17) \\
\text { No significant difference in CV death, hHF }\end{array}$ \\
\hline & Liraglutide & $\begin{array}{l}\text { LEADER (2016) } \\
\mathrm{n}=9340\end{array}$ & 3.8 & $\begin{array}{l}\text { Either: } \\
\text { 1. } \geq 50 \text { years with established } \\
\text { CVD } \\
\text { 2. } \geq 60 \text { years with at least one } \mathrm{CV} \\
\text { risk factor }\end{array}$ & $\begin{array}{l}\text { Lower 3p-MACE } \\
\text { HR } 0.87 \text { (0.78 to } 0.97) \\
\text { Lower CV-related deaths HR } 0.78 \text { ( } 0.66 \text { to } 0.93) \\
\text { Lower all-cause mortality HR } 0.85(0.74 \text { to } 0.97) \\
\text { No significant difference in hHF, non-fatal MI, non-fatal stroke }\end{array}$ \\
\hline & Semaglutide & $\begin{array}{l}\text { SUSTAIN-6 (2016) } \\
\mathrm{n}=3297\end{array}$ & 2.1 & $\begin{array}{l}83 \% \text { with established CVD, CKD or both } \\
17 \% \text { with CV risk factors }\end{array}$ & $\begin{array}{l}\text { Lower 3p-MACE HR } 0.74 \text { ( } 0.58 \text { to } 0.95) \\
\text { Lower rate of non-fatal MI HR } 0.74(0.51 \text { to } 1.08) \\
\text { Lower rate of non-fatal stroke HR } 0.61(0.38 \text { to } 0.99) \\
\text { No significant difference in CV deaths, hHF }\end{array}$ \\
\hline & Dulaglutide & $\begin{array}{l}\text { REWIND } \\
(2019) \\
\mathrm{n}=9622\end{array}$ & 5.4 & $\begin{array}{l}\geq 50 \text { years old } \\
31 \% \text { with established CVD } \\
69 \% \text { with CV risk factors }\end{array}$ & 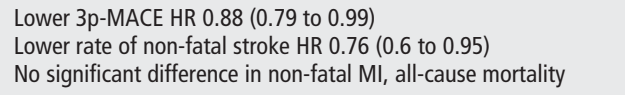 \\
\hline & Albiglutide & $\begin{array}{l}\text { HARMONY } \\
(2018) \\
\mathrm{n}=9400\end{array}$ & 1.6 & $\begin{array}{l}\geq 40 \text { years old } \\
\text { Established CVD }\end{array}$ & $\begin{array}{l}\text { Lower 3p-MACE HR } 0.78(0.65 \text { to } 0.90) \\
\text { Lower rate of fatal or non-fatal MI HR } 0.75 \text { ( } 0.61 \text { to } 0.90)\end{array}$ \\
\hline
\end{tabular}

ACS, acute coronary syndrome; CARMELINA, Cardiovascular Safety and Renal Microvascular Outcome Study With Linagliptin; CAROLINA, CARdiovascular Outcome study of LINAgliptin versus glimepiride in patients with type 2 diabetes; CKD, chronic kidney disease; CREDENCE, Canagliflozin and Renal Endpoints in Diabetes with Established Nephropathy Clinical Evaluation; CVD, cardiovascular disease; CVOT, cardiovascular outcomes trials; DECLARE-TIMI, Dapagliflozin Effect on Cardiovascular Events-Thrombolysis in Myocardial Infarction; DPP-4i, dipeptidylpeptidase-4 inhibitor; eGFR, estimated glomerular filtration rate; EMPA-REG, The Empagliflozin Cardiovascular Outcome Event Trial in Type 2 Diabetes Mellitus Patients-Removing Excess Glucose; ESRD, endstage renal disease; EXAMINE, Examination of Cardiovascular Outcomes with Alogliptin versus Standard of Care; GLP-1 RA, glucagon-like peptide-1 receptor agonist; HF, heart failure; hHF, hospitalisation for heart failure; MI, myocardial infarction; 3p-MACE, three-point major adverse cardiovascular event (composite of cardiovascular death, non-fatal myocardial infarction, nonfatal stroke); $4 \mathrm{p}-\mathrm{MACE}$, four-point major adverse cardiovascular event (composite of cardiovascular death, non-fatal myocardial infarction, non-fatal stroke, or hospitalisation for unstable angina); RRT, renal replacement therapy; SAVOR-TIMI, Saxagliptin Assessment of Vascular Outcomes Recorded in Patients with Diabetes Mellitus -Thrombolysis in Myocardial Infarction; SGLT-2i, sodium glucose transporter-2 inhibitor; TECOS, Trial to Evaluate Cardiovascular Outcomes After Treatment With Sitagliptin. 
placebo, thought to be due to rapid $\mathrm{HbA}_{1 \mathrm{c}}$ reductions in patients with pre-existing retinopathy. ${ }^{50}$

GLP1-RAs have differing structures and duration of action and the CVOTs involving these agents varied in size and patient characteristics, making the findings inconsistent. A meta-analysis of the seven largest trials (ELIXA, ${ }^{51}$ EXSCEL, ${ }^{52}$ LEADER, ${ }^{53}$ SUSTAIN$6,{ }^{50}$ REWIND, ${ }^{54}$ PIONEER- $6,{ }^{55}$ HARMONY ${ }^{56}$ ) studying 56004 patients showed a $12 \%$ reduction in the $3 \mathrm{p}-\mathrm{MACE}$ associated with GLP1-RAs, without heterogeneity across patient subgroups. ${ }^{49}$ This observation was due to reduced rates of CV death (12\%), fatal or nonfatal stroke (16\%) and fatal or nonfatal MI (9\%). There was also a reduction in all-cause mortality (12\%) and hHF (9\%), predominantly seen with albiglutide. ${ }^{56}$ There is some heterogeneity between agents-exenatide and lixisenatide have not demonstrated improved CV outcomes. ${ }^{51}{ }^{52}$ A composite renal outcome was reduced by $17 \%$ for all GLP1-RA, mainly due to a reduction in new macroalbuminuria.

Liraglutide (LEADER) was the first GLP1-RA to prove superiority with a $13 \%$ decrease in 3 p-MACE, attributed to a $22 \%$ decrease in CV deaths after 3.8 years of follow-up. ${ }^{53}$ There was no significant effect on the hHf and non-fatal rates of MI and stroke. All cause mortality decreased by $15 \%$. Liraglutide's benefits were observed in a high CV risk cohort $(81.3 \%$ had established $\mathrm{CV}$ disease, $\mathrm{HbA}_{1 \mathrm{c}}$ averaged $8.7 \%$ and a significant number had CKD stage 3 or greater), with mean diabetes duration of 12.8 years; therefore, it is uncertain whether these results could be extrapolated into lower CV risk patients.

Dulaglutide was superior to placebo in achieving a $3 \mathrm{p}-\mathrm{MACE}$ (HR $0.88 ; 0.79$ to 0.99 ) over 5.4 years due to the significant benefit against non-fatal stroke (HR 0.76 ; 0.6 to 0.95 ). In contrast to other studies, REWIND was the longest trial studying GLP1-RAs with only 31\% of participants with established CVD and otherwise all had a low baseline $\mathrm{HbA}_{1 \mathrm{c}} .{ }^{54}$

Semaglutide (SUSTAIN-6) led to a $26 \%$ reduction in the $3 \mathrm{p}-$ MACE after 2.1 years of follow-up, attributed to a $26 \%$ reduction in non-fatal MI and a 39\% decrease in the rate of non-fatal stroke. Semaglutide did not affect hHF outcomes or CV-related deaths. Comparable to the LEADER trial, the participants also had high $\mathrm{CV}$ risk. ${ }^{50}$ Semaglutide led to a significant $76 \%$ increase in retinopathy complications (HR 1.76 (1.11 to 2.78), not seen in other trials. This could be attributed to the large and rapid $\mathrm{HbA}_{1 \mathrm{c}}$ improvement observed $(-0.7 \%$ and $-1.0 \%$ with Semaglutide 0.5 $\mathrm{mg}$ and $1.0 \mathrm{mg}$, respectively), not seen with most other GLP1-RAs. The significant Hba1C improvement might also be responsible for the CV benefit observed. More recently, oral semaglutide studied in PIONEER-6 only showed non-inferiority to placebo in 3pMACE. $^{55}$

Finally, albiglutide (HARMONY outcomes) reduced the 3pMACE relative risk by $22 \%$ over a median of 1.6 years. All participants had established CVD, cerebrovascular disease, heart failure or peripheral arterial disease. Alike SUSTAIN-6 and LEADER, the participants had a high baseline HbA1c (median 8.7\%). The CV effects were irrespective of the small glucose-lowering effect $(-0.52 \%)^{56}$; therefore, challenging the possibility that the cardioprotective effects of GLP-1 RAs are solely linked to glucose-lowering efficacy. This study did not look at retinopathy outcomes, which would help infer whether the increased retinopathy events in SUSTAIN-6 (Semaglutde) were an undesirable effect of the drug or were due to the relative rapid reduction in $\mathrm{HbA}_{1 \mathrm{c}}$.

DPP-4 inhibitors (DPP-4i)

DPP-4i (gliptins) increase the bioavailability of native GLP-1. They improve glycaemic control by increasing endogenous insulin and suppressing glucagon. They demonstrate modestly improved glycaemic control, but smaller $\mathrm{HbA}_{1 \mathrm{C}}$ improvements compared with GLP1-RAs (8-10 mmol/mol (0.8-1.0\%)). They are weight neutral with a low risk of hypoglycaemia, and few side effects. ${ }^{57}$ A slight increase in risk of pancreatitis has been linked to their use. ${ }^{58}$

All CVOTs studying DPP-4i (TECOS (sitagliptin), ${ }^{59}$ EXAMINE (alogliptin), ${ }^{60}$ SAVOR-TIMI53 (saxagliptin), ${ }^{61}$ VIVIDD (vildagliptin in ventricular dysfunction diabetes), ${ }^{62}$ CARMELINA (linagliptin) $)^{63}$ have demonstrated CV safety, but no evidence of $\mathrm{CV}$ protection. Sitagliptin (TECOS) was not inferior to placebo in terms of four-point MACE outcomes, which included hospitalisations for unstable angina, and hospitalisations with heart failure in patients with established CVD. ${ }^{59}$

Saxagliptin and alogliptin may exacerbate heart failure. Saxagliptin contributed to a significant $27 \%$ increase in $\mathrm{hHF},{ }^{61}$ and alogliptin was associated with a non-significant $19 \%$ increase in hHF. ${ }^{60}$ Meta-analysis confirmed an increased risk of hHf by $25 \% .{ }^{64}$ Alogliptin was studied in a high CV risk population that were recently hospitalised with ACS. This might have been a confounding factor contributing to the higher rates of heart failure observed. EXAMINE, however, provides reassuring data that alogliptin does not increase CV morbidity or mortality over 18 months in patients with a recent ACS.

Linagliptin (CAROLINA) had comparable 3p-MACE rates to the sulfonylurea glimepiride in 6033 adults with T2D over a median of 6 years. Lower incidence of hypoglycaemia and weight gain was noted with linagliptin. ${ }^{65}$ In patients with CKD, linagliptin can be given at a standard dose irrespective of the renal function. To date, CARMELINA is the only trial evaluating kidney outcomes of DPP-4i in patients with T2D at high cardiorenal risk. Linagliptin did not cause renal disease progression, irrespective of the level of renal impairment, but did demonstrate lower rates of albuminuria progression (HR $0.86)$ compared with placebo. ${ }^{66}$

\section{Sodium glucose transporter-2 inhibitors (SGLT-2i)}

SGLT-2i (gliflozins) inhibit SGLT-2 in the proximal convoluted tubule, hence promoting glycosuria. This improves glycaemic control and leads to weight loss of up to $5 \mathrm{~kg} .{ }^{67}$ They have comparable glycaemic efficacy to conventional treatments. ${ }^{68}$ As their action depends on GFR, their glucose-lowering effect decreases with worsening renal function. Both dapagliflozin and canagliflozin are comparable to glimepiride in glycaemic lowering when added to metformin. ${ }^{69} 70$ Canagliflozin and empagliflozin produce greater $\mathrm{HbA}_{1 \mathrm{c}}$ reductions than sitagliptin irrespective of their dose, when added to metformin. ${ }^{71} 72$ The risk of hypoglycaemia in the absence of insulin or sulfonylureas is low. ${ }^{67}$

Enhanced natriuresis and glycosuria-driven osmotic diuresis, with subsequent inhibition of the renin-angiotensin system, contributes to blood pressure reduction. Other improvements also noted are reduced arterial stiffness, intravascular volume contraction and intrarenal haemodynamic alterations. ${ }^{73}$ They are generally associated with an all-cause mortality reduction, irrespective of the $\mathrm{HbA}_{1 \mathrm{C}}$, body weight, blood pressure and serum uric acid reductions seen in studies, therefore linking it to the diuretic and natriuretic properties of the drugs. ${ }^{68}$ Current guidelines advise initiation of SGLT-2i in T2D only when eGFR is $>60 \mathrm{~mL} / \mathrm{min} / 1.73 \mathrm{~m}^{2}$ and discontinuation once below $45 \mathrm{~mL} / \mathrm{min} / 1.73 \mathrm{~m}^{2}$. Their most common side effect is urinary tract infection, or genital mycotic infections. SGLT-2i have been associated with a slightly increased risk of euglycaemic diabetic ketoacidosis ${ }^{74}$ and Fournier's gangrene. ${ }^{75}$ An increased risk of amputation was seen with canagliflozin in the CANVAS trial, ${ }^{76}$ which was not reproduced in a subsequent study. 
Nevertheless, it is prudent to stop canagliflozin if a significant lower limb complication arises and avoid in patients at high risk.

A recent meta-analysis of three large CVOTs studying the effects of empagliflozin (EMPA-REG), ${ }^{77}$ canagliflozin (CANVASPROGRAM) ${ }^{76}$ and dapagliflozin (DECLARE-TIMI 58$)^{78}$ on CV and renal outcomes demonstrated benefits in all endpoints, the extent of which depended on the patient characteristics in which they were used. SGLT-2i, as a group, led to an $11 \%$ reduction in the 3 p-MACE, an effect entirely confined to patients with underlying atherosclerotic CVD (HR 0.86 (0.80 to 0.93 ) vs HR 1.00 (0.87 to 1.16$))$. MI risk was reduced by $15 \%$ and $\mathrm{CV}$ death by $20 \%$ (38\% for empagliflozin, 13\% for canagliflozin). SGLT-2i had no effect on stroke in both subgroups. ${ }^{79}$

In DECLARE-TIMI $58,{ }^{78}$ dapagliflozin did not lead to a significant 3p-MACE (HR 0.93 (0.84 to 1.03)) or CV death reduction, but only $40.6 \%$ of the participants had established CVD, as opposed to $100 \%$ and $65.6 \%$ in EMPA-REG and CANVAS, respectively. In their respective studies, both empagliflozin and canagliflozin led to a 14\% reduction of the 3p-MACE. Meta-analysis showed that in patients with atherosclerotic CVD, empagliflozin had a more pronounced effect on CV death than canagliflozin or dapagliflozin. Whether this is attributed to the underlying patient characteristics or specific drug differences is undetermined.

In the same meta-analysis, a significant reduction of $23 \%$ was seen in the risk for the composite of $\mathrm{CV}$ death and $\mathrm{hHf}$, irrespective of underlying CV characteristics. hHF was reduced by $31 \%$ in both subgroups (35\% for empagliflozin, $33 \%$ for canagliflozin and $27 \%$ for dapagliflozin). Interestingly, patients with worse renal function had greater reductions in hHF.

SGLT-2i also caused a robust $45 \%$ reduction in the composite renal outcomes, which were more pronounced in patients with better renal function at baseline. ${ }^{79}$ This comprised reductions in

\section{Main messages}

- Therapeutic options for the management of glucose in people with type 2 diabetes (T2D) have grown in recent years. Large cardiovascular outcomes trials have given an insight into the effects of these drugs on non-glucose-related outcomes.

- Glucagon-like-peptide-1 receptor agonists (GLP-1 RA) are injectable agents that have the positive benefit of improving glucose control and reducing weight. They frequently, however, cause gastrointestinal side effects. Some GLP-1 RAs have shown positive benefits in reduction of cardiovascular outcomes.

- Sodium glucose transporter-2 inhibitors (SGLT-2i) are oral agents that improve glucose and weight by inducing glycosuria. They may cause urogenital infections and occasionally euglycaemic ketoacidosis. Large randomised trials of SGLT-2i have shown benefits in cardiovascular outcomes, especially heart failure and stroke. In addition, renal outcome studies suggest a reduction in the risk of progressive renal disease.

Current research questions

- Do GLP-1 RAs have a role in the prevention of cardiovascular disease (CVD) in people with or without T2D?

- Do SGLT2-i agents have a role in the prevention of CVD or renal disease in people with or without T2D?

- Do GLP-1 RAs or SGLT-2i agents have a role in the prevention of T2D in people at high risk for developing the condition? albuminuria progression, worsening renal function, advancement of ESRF and death from a renal cause. Macroalbuminuria rates were significantly reduced by $38 \%$ for empagliflozin, ${ }^{80} 42 \%$ for canagliflozin $^{81}$ and $29 \%$ for dapagliflozin, ${ }^{82}$ in their respective studies.

The CREDENCE study ${ }^{83}$ looked at cardiorenal outcomes in two groups of patients with T2D and albuminuric CKD-50.4\% had a history of CVD. All participants were already on ACE inhibitors. At median follow-up of 2.62 years, canagliflozin was associated with a $34 \%$ reduction in the renal specific composite (doubling of serum creatinine (HR 0.60), ESKD (HR 0.68), renal or CV death (HR 0.72)), without heterogeneity across the primary and secondary prevention groups. Urinary albumin creatinine ratio (ACR) was 31\% lower in the canagliflozin group. This was in addition to a $20 \%$ relative risk decline in all three components of the $3 \mathrm{p}-\mathrm{MACE}$, and $39 \%$ reductions in hHf, studied as secondary outcomes. Canagliflozin is, therefore, the only antihyperglycaemic drug to show effectiveness in reducing cardiorenal outcomes in primary prevention groups with T2D and CKD. It also demonstrates cardiorenal efficacy across all stages of CKD, highest in the eGFR groups of $45-60 \mathrm{~mL} / \mathrm{min} / 1.73 \mathrm{~m}^{2}$ and urinary ACR $>1000 \mathrm{mg} / \mathrm{mL}$.

\section{CONCLUSIONS}

The management of patients with diabetes involves a multidisciplinary team approach, with the patient at the centre of their care, and indeed new guidelines emphasise the need to tailor the approach to the needs of the patient. New therapeutics for T2D enables us to approach each patient as an individual, and personalise therapy according to their preferences, complications and comorbidities. The positive benefits of newer therapies on other conditions such as weight, blood pressure, CVD and renal disease, plus the lack of hypoglycaemia with these drugs, suggest

\section{Key references}

1. Cho NH, Shaw JE, Karuranga S et al. IDF Diabetes Atlas: Global estimates of diabetes prevalence for 2017 and projections for 2045. Diabetes Res Clin Pract 2018;138:271-281.

2. Davies MJ, D'Alessio DA, Fradkin J, et al. Management of hyperglycaemia in type 2 diabetes, 2018. A consensus report by the American Diabetes Association (ADA) and the European Association for the Study of Diabetes (EASD). Diabetologia. 2018;41(12):2669-2701.

3. Boussageon R, Bejan-Angoulvant T, Saadatian-Elahi M, et al. Effect of intensive glucose lowering treatment on all-cause mortality, cardiovascular death, and microvascular events in type 2 diabetes: meta-analysis of randomised controlled trials. BMJ. 2011;343:4169

4. Kristensen SL, Rørth R, Jhund PS, et al. Cardiovascular, mortality, and kidney outcomes with GLP-1 receptor agonists in patients with type 2 diabetes: a systematic review and meta-analysis of cardiovascular outcome trials. Lancet Diabetes Endocrinol. 2019;7:776-85.

5. Udell JA, Cavender MA, Bhatt DL, et al. Glucose-lowering drugs or strategies and cardiovascular outcomes in patients with or at risk for type 2 diabetes: a meta-analysis of randomised controlled trials. Lancet Diabetes Endocrinol. 2015;3:356-66.

6. Zelniker TA, Wiviott SD, Raz I, et al. SGLT2 inhibitors for primary and secondary prevention of cardiovascular and renal outcomes in type 2 diabetes: a systematic review and meta-analysis of cardiovascular outcome trials. Lancet. 2019;393:31-9. 


\section{Self assessment questions}

1. A 56-year-old man with type 2 diabetes was seen in a diabetes clinic for review. His diabetes clinician suggested that his glucose control was poor, and that he needed another agent in addition to metformin. His body mass index was $27 \mathrm{~kg} / \mathrm{m}^{2}$ and he had evidence of proteinuria. His estimated glomerular filtration rate was $>60 \mathrm{~mL} / \mathrm{min} / 1.73 \mathrm{~m}^{2}$. Which of the following agents is the most appropriate to prescribe?
a. Di-peptidlypeptidase-4 inhibitor (eg, sitagliptin).
b. Insulin.
c. Pioglitazone.
d. Sodium glucose transporter-2 inhibitor (eg, canagliflozin).
e. Sulfonylurea (eg, gliclazide).

2. A 46-year-old woman with type 2 diabetes was seen by her practice nurse with poor glycaemic control. She was treated with metformin and sitagliptin at maximum tolerated doses. She had a history of myocardial infarction. Her body mass index was $37 \mathrm{~kg} /$ $\mathrm{m}^{2}$. Which of the following agents is most appropriate to prescribe?
a. Add insulin.
b. Add pioglitazone.
c. Add sodium glucose transporter-2 inhibitor (eg, canagliflozin).
d. Add sulfonylurea (eg, gliclazide).
e. Stop sitaliptin and add glucagon-like peptide-1 receptor antagonist (eg, liraglutide).

3. An 82-year-old man with type 2 diabetes was admitted to hospital following a fall. He had type 2 diabetes and a history of cognitive impairment. His glycated haemoglobin was noted to be $68 \mathrm{mmol} /$ $\mathrm{mol}(8.5 \%)$, treated with metformin. He had no symptoms related to his diabetes. Which of the following is the correct therapeutic option?
a. Glucagon-like peptide-1 receptor antagonist (eg, liraglutide).
b. Insulin.
c. No additional treatment needed.
d. Sodium glucose transporter-2 inhibitor (eg, canagliflozin).
e. Sulfonylurea (eg, gliclazide).

4. A 45-year-old man with type 2 diabetes was seen by his general practitioner, complaining of nausea, abdominal pain and vomiting. His diabetes medications included metformin, sitagliptin and empagliflozin, the latter of which was started 3 months earlier. On examination, blood pressure was $96 / 54 \mathrm{~mm}$ $\mathrm{Hg}$, pulse 109 and he was afebrile. Capillary blood glucose was $10.5 \mathrm{mmol} / \mathrm{L}$. Which of the following tests should be immediately undertaken?
a. Chest X-ray.
b. ECG.
c. N-terminal pro-BNP (brain natriuretic peptide).
d. Plasma ketones.
e. Pulse oximetry.

5. A 76-year-old man was seen for diabetes review. He had type 2 diabetes for 12 years, and stable chronic kidney disease stage $3 \mathrm{~b}$. He was treated with metformin $500 \mathrm{mg}$ two times a day, linagliptin $5 \mathrm{mg}$ one time a day and gliclazide $80 \mathrm{mg}$ two times a day. His glycated haemoglobin was $50 \mathrm{mmol} / \mathrm{mol}(6.7 \%)$. Which of the following is most appropriate?
a. Add glucagon-like peptide-1 receptor antagonist (eg, liraglutide).
b. Add sodium glucose transporter-2 inhibitor (eg, canagliflozin).
c. No change required.
d. Reduce and consider stopping gliclazide.
e. Stop metformin.

that these agents should be higher in the therapeutic pathway for many patients with these comorbidities. In particular, GLP-1 RAs and SGLT-2i may be prescribed more frequently in patients to prevent weight gain, renal or CVD. Non-specialists need to be aware of the effects and adverse effects of these agents as they are likely to be prescribed more frequently in the future.

Contributors JT wrote the main sections on glucose control and older/newer agents. AC and WW contributed sections, referenced, reviewed and revised the manuscript. TAC conceived the idea, wrote and rewrote various sections including the selfassessment questions and is the guarantor.

Funding The authors have not declared a specific grant for this research from any funding agency in the public, commercial or not-for-profit sectors.

Competing interests None declared.

Patient consent for publication Not required.

Provenance and peer review Commissioned; externally peer reviewed.

\section{ORCID iD}

Tahseen Ahmad Chowdhury http://orcid.org/0000-0001-8878-2331

\section{REFERENCES}

Cho NH, Shaw JE, Karuranga S, et al. IDF diabetes atlas: global estimates of diabetes prevalence for 2017 and projections for 2045. Diabetes Res Clin Pract 2018;138:271-81.

2 Zheng Y, Ley SH, Hu FB. Global aetiology and epidemiology of type 2 diabetes mellitus and its complications. Nat Rev Endocrinol 2018;14:88-98.

3 Tatti P, Di Mauro P, Masselli L, et al. Prevention of diabetic eye disease: the commonest cause of blindness in individuals younger than 65 years. Clin Ophthalmol 2010;4:1291-8.

4 Tuttle KR, Bakris GL, Bilous RW, et al. Diabetic kidney disease: a report from an ADA consensus conference. Diabetes Care 2014;37:2864-83.

5 Tun NN, Arunagirinathan G, Munshi SK, et al. Diabetes mellitus and stroke: a clinical update. World J Diabetes 2017:8:235-48.

6 Li X, Jiao Y, Xing Y, et al. Diabetes mellitus and risk of hepatic Fibrosis/Cirrhosis. Biomed Res Int 2019;2019:5308308.

7 Starup-Linde J, Karlstad 0, Eriksen SA, et al. CARING (CAncer Risk and INsulin analoGues): the association of diabetes mellitus and cancer risk with focus on possible determinants - a systematic review and a meta-analysis. Curr Drug Saf 2013;8:296-332.

8 Bell DSH. Heart failure: a serious and common comorbidity of diabetes. Clinical Diabetes 2004;22:61-5.

9 Schellenberg ES, Dryden DM, Vandermeer B, et al. Lifestyle interventions for patients with and at risk for type 2 diabetes: a systematic review and meta-analysis. Ann Intern Med 2013;159:543-51

10 World health organisation (who). definition and diagnosis of diabetes mellitus and intermediate hyperglycaemia, 2006. Available: https://www.who.int/diabetes/publica tions/diagnosis_diabetes2006/en/ [Accessed 16 Feb 2020].

11 World Health Organisation. Use of glycated haemoglobin ( $\mathrm{HbA1c}$ ) in the diagnosis of diabetes mellitus, 2011. Available: https://www.who.int/diabetes/publications/reporthba1c_2011.pdf [Accessed 16 Feb 2020].

12 Radin MS. Pitfalls in hemoglobin A1c measurement: when results may be misleading. J Gen Intern Med 2014;29:388-94

13 Fox C, Kilvert A. Intensive education for lifestyle change in diabetes. BMJ 2003:327:1120-1.

14 Boussageon R, Bejan-Angoulvant T, Saadatian-Elahi M, et al. Effect of intensive glucose lowering treatment on all cause mortality, cardiovascular death, and microvascular events in type 2 diabetes: meta-analysis of randomised controlled trials. BMJ 2011;343:4169.

15 Coca SG, Ismail-Beigi F, Haq N, et al. Role of intensive glucose control in development of renal end points in type 2 diabetes mellitus: systematic review and meta-analysis intensive glucose control in type 2 diabetes. Arch Intern Med 2012;172:761-9.

16 Arnold LW, Wang Z. The HbA1c and all-cause mortality relationship in patients with type 2 diabetes is J-shaped: a meta-analysis of observational studies. Rev Diabet Stud 2014;11:138-52.

17 Ismail-Beigi F, Craven T, Banerji MA, et al. Effect of intensive treatment of hyperglycaemia on microvascular outcomes in type 2 diabetes: an analysis of the Accord randomised trial. Lancet 2010;376:419-30.

18 Davies MJ, D'Alessio DA, Fradkin J, et al. Management of hyperglycaemia in type 2 diabetes, 2018. A consensus report by the American diabetes association (ADA) and the European association for the study of diabetes (EASD). Diabetologia 2018:61:2461-98.

19 National Institute for Health and Clinical Excellence. Type 2 diabetes in adults: management. NICE guideline [NG28]. Available: https://www.nice.org.uk/guidance/ng28/chapter/ 1-Recommendations\#blood-glucose-management-2 [Accessed 29 Dec 2019]. 
20 American Diabetes Association. 6. Glycemic Targets: Standards of Medical Care in Diabetes-2018. Diabetes Care 2018;41:55-64.

21 Rockville MD. Food and drug administration: diabetes mellitus-evaluating cardiovascular risk in new antidiabetic therapies to treat type 2 diabetes, 2008. Available: http:// www.fda.gov/downloads/Drugs/GuidanceComplianceRegulatoryInformation/Guidanc es/ucm071627.pdf

22 Nissen SE, Wolski K. Effect of rosiglitazone on the risk of myocardial infarction and death from cardiovascular causes. N Engl J Med 2007;356:2457-71.

23 Chaplin S. NICE guidance on managing type 2 diabetes in adults, 2016: 22-9.

24 Stumvoll M, Nurjhan N, Perriello G, et al. Metabolic effects of metformin in non-insulindependent diabetes mellitus. N Eng/ J Med 1995;333:550-4

25 DeFronzo RA, Stonehouse AH, Han J, et al. Relationship of baseline HbA1c and efficacy of current glucose-lowering therapies: a meta-analysis of randomized clinical trials. Diabet Med 2010;27:309-17

26 Domecq JP, Prutsky G, Leppin A, et al. Clinical review: drugs commonly associated with weight change: a systematic review and meta-analysis. J Clin Endocrinol Metab 2015;100:363-70

27 Bailey CJ, Turner RC, Metformin TRC. Metformin. N Engl J Med 1996;334:574-9.

28 Lazarus B, Wu A, Shin J-I, et al. Association of metformin use with risk of lactic acidosis across the range of kidney function: a community-based cohort study. JAMA Intern Med 2018;178:903-10.

29 Kooy $A$, de Jager J, Lehert $P$, et al. Long-Term effects of metformin on metabolism and microvascular and macrovascular disease in patients with type 2 diabetes mellitus. Arch Intern Med 2009;169:616-25.

30 Landman GWD, Kleefstra N, van Hateren KJJ, et al. Metformin associated with lower cancer mortality in type 2 diabetes: ZODIAC-16. Diabetes Care 2010;33:322-6.

31 Yin M, Zhou J, Gorak EJ, et al. Metformin is associated with survival benefit in cancer patients with concurrent type 2 diabetes: a systematic review and meta-analysis. Oncologist 2013;18:1248-55.

32 Inzucchi SE, Bergenstal RM, Buse JB, et al. Management of hyperglycemia in type 2 diabetes: a patient-centered approach: position statement of the American diabetes association (ADA) and the European association for the study of diabetes (EASD). Diabetes Care 2012:35:1364-79.

33 Takahashi A, Nagashima K, Hamasaki A, et al. Sulfonylurea and glinide reduce insulin content, functional expression of K(ATP) channels, and accelerate apoptotic beta-cell death in the chronic phase. Diabetes Res Clin Pract 2007;77:343-50.

34 Schopman JE, Simon ACR, Hoefnagel SJM, Hoekstra JB, et al. The incidence of mild and severe hypoglycaemia in patients with type 2 diabetes mellitus treated with sulfonylureas: a systematic review and meta-analysis. Diabetes Metab Res Rev 2014:30:11-22.

35 Yu O, Azoulay L, Yin H, et al. Sulfonylureas as initial treatment for type 2 diabetes and the risk of severe hypoglycemia. Am J Med 2018;131:317.

36 Jennings AM, Wilson RM, Ward JD. Symptomatic hypoglycemia in NIDDM patients treated with oral hypoglycemic agents. Diabetes Care 1989;12:203-8.

37 Lipska KJ, Ross JS, Wang Y, et al. National trends in US hospital admissions for hyperglycemia and hypoglycemia among Medicare beneficiaries, 1999 to 2011. JAMA Intern Med 2014;174:1116-24.

38 Simpson SH, Lee J, Choi S, et al. Mortality risk among sulfonylureas: a systematic review and network meta-analysis. Lancet Diabetes Endocrinol 2015;3:43-51.

39 Lebovitz HE, Dole JF, Patwardhan $\mathrm{R}$, et al. Rosiglitazone monotherapy is effective in patients with type 2 diabetes. J Clin Endocrinol Metab 2001;86:280-8.

40 Lago RM, Singh PP, Nesto RW. Congestive heart failure and cardiovascular death in patients with prediabetes and type 2 diabetes given thiazolidinediones: a meta-analysis of randomised clinical trials. Lancet 2007;370:1129-36.

41 Grey A, Bolland M, Gamble G, et al. The peroxisome proliferator-activated receptor-gamma agonist rosiglitazone decreases bone formation and bone minera density in healthy postmenopausal women: a randomized, controlled trial. J Clin Endocrinol Metab 2007;92:1305-10.

42 Dormandy J, Bhattacharya M, van Troostenburg de Bruyn A-R, de Bruyn A-R van T, et al. Safety and tolerability of pioglitazone in high-risk patients with type 2 diabetes: an overview of data from proactive. Drug Saf 2009;32:187-202.

43 Lewis JD, Ferrara A, Peng T, et al. Risk of bladder cancer among diabetic patients treated with pioglitazone: interim report of a longitudinal cohort study. Diabetes Care 2011;34:916-22.

44 Deeg MA, Buse JB, Goldberg RB, et al. Pioglitazone and rosiglitazone have different effects on serum lipoprotein particle concentrations and sizes in patients with type 2 diabetes and dyslipidemia. Diabetes Care 2007;30:2458-64.

45 Home PD, Pocock SJ, Beck-Nielsen H, et al. Rosiglitazone evaluated for cardiovascular outcomes in oral agent combination therapy for type 2 diabetes (record): a multicentre, randomised, open-label trial. Lancet 2009;373:2125-35.

46 Koliaki C, Doupis J. Incretin-Based therapy: a powerful and promising weapon in the treatment of type 2 diabetes mellitus. Diabetes Ther 2011;2:101-21.

47 Nauck M, Stöckmann F, Ebert $R$, et al. Reduced incretin effect in type 2 (non-insulindependent) diabetes. Diabetologia 1986;29:46-52.

48 Mentlein R, Gallwitz B, Schmidt WE. Dipeptidyl-peptidase IV hydrolyses gastric inhibitory polypeptide, glucagon-like peptide-1(7-36)amide, peptide histidine methionine and is responsible for their degradation in human serum. Eur J Biochem 1993;214:829-35.
49 Kristensen SL, Rørth R, Jhund PS, et al. Cardiovascular, mortality, and kidney outcomes with GLP-1 receptor agonists in patients with type 2 diabetes: a systematic review and meta-analysis of cardiovascular outcome trials. Lancet Diabetes Endocrinol 2019:7:776-85.

50 Marso SP, Bain SC, Consoli A, et al. Semaglutide and cardiovascular outcomes in patients with type 2 diabetes. N Engl J Med 2016:375:1834-44.

51 Pfeffer MA, Claggett B, Diaz R, et al. Lixisenatide in patients with type 2 diabetes and acute coronary syndrome. N Engl J Med 2015;373:2247-57.

52 Holman RR, Bethel MA, Mentz RJ, et al. Effects of once-weekly exenatide on cardiovascular outcomes in type 2 diabetes. N Engl J Med 2017;377:1228-39.

53 Mann JFE, Ørsted DD, Brown-Frandsen K, et al. Liraglutide and renal outcomes in type 2 diabetes. N Engl J Med 2017;377:839-48.

54 Gerstein HC, Colhoun HM, Dagenais GR, et al. Dulaglutide and cardiovascular outcomes in type 2 diabetes (REWIND): a double-blind, randomised placebo-controlled trial. Lancet 2019;394:121-30.

55 Husain M, Birkenfeld AL, Donsmark M, et al. Oral Semaglutide and cardiovascular outcomes in patients with type 2 diabetes. N Engl J Med 2019:381:841-51.

56 Hernandez AF, Green JB, Janmohamed S, et al. Albiglutide and cardiovascular outcomes in patients with type 2 diabetes and cardiovascular disease (harmony outcomes): a double-blind, randomised placebo-controlled trial. Lancet 2018;392:1519-29.

57 Holst JJ, Deacon CF. Glucagon-Like peptide-1 mediates the therapeutic actions of DPP-IV inhibitors. Diabetologia 2005;48:612-5.

58 Meier JJ, Nauck MA. Risk of pancreatitis in patients treated with incretin-based therapies. Diabetologia 2014;57:1320-4.

59 Green JB, Bethel MA, Armstrong PW, et al. Effect of sitagliptin on cardiovascular outcomes in type 2 diabetes. N Engl J Med 2015;373:232-42.

60 White WB, Cannon CP, Heller SR, et al. Alogliptin after acute coronary syndrome in patients with type 2 diabetes. N Engl J Med 2013;369:1327-35.

61 Scirica BM, Bhatt DL, Braunwald E, et al. Saxagliptin and cardiovascular outcomes in patients with type 2 diabetes mellitus. N Engl J Med 2013;369:1317-26.

62 McInnes G, Evans M, Del Prato S, et al. Cardiovascular and heart failure safety profile of vildagliptin: a meta-analysis of 17000 patients. Diabetes Obes Metab 2015; 17:1085-92

63 Rosenstock J, Perkovic V, Johansen OE, et al. Effect of linagliptin vs placebo on major cardiovascular events in adults with type 2 diabetes and high cardiovascular and renal risk: the CARMELINA randomized clinical trial. JAMA 2019:321:69.

64 Udell JA, Cavender MA, Bhatt DL, et al. Glucose-Lowering drugs or strategies and cardiovascular outcomes in patients with or at risk for type 2 diabetes: a meta-analysis of randomised controlled trials. Lancet Diabetes Endocrinol 2015:3:356-66.

65 Rosenstock J. CAROLINA®: cardiovascular safety and renal microvascular outcome with linagliptin in patients with T2D at high vascular risk. Oral presentation at the 79th Scientific Sessions of the American Diabetes Association (ADA), San Francisco, California, 2019:30-18.

66 Williams DM, Nawaz A, Evans M. Renal outcomes in type 2 diabetes: a review of cardiovascular and renal outcome trials. Diabetes Ther 2020;11:369-86.

67 Rosenwasser RF, Sultan S, Sutton D, et al. SGLT-2 inhibitors and their potential in the treatment of diabetes. Diabetes Metab Syndr Obes 2013;6:453-67.

68 Vasilakou D, Karagiannis T, Athanasiadou E, et al. Sodium-Glucose cotransporter 2 inhibitors for type 2 diabetes: a systematic review and meta-analysis. Ann Intern Med 2013:159:262-74.

69 Nauck MA, Del Prato S, Meier JJ, et al. Dapagliflozin versus glipizide as add-on therapy in patients with type 2 diabetes who have inadequate glycemic control with metformin: a randomized, 52-week, double-blind, active-controlled noninferiority trial. Diabetes Care 2011:34:2015-22.

70 Cefalu WT, Leiter LA, Yoon K-H, et al. Efficacy and safety of canagliflozin versus glimepiride in patients with type 2 diabetes inadequately controlled with metformin (CANTATA-SU): 52 week results from a randomised, double-blind, phase 3 non-inferiority trial. Lancet 2013;382:941-50.

71 Lavalle-González FJ, Januszewicz A, Davidson J, et al. Efficacy and safety of canagliflozin compared with placebo and sitagliptin in patients with type 2 diabetes on background metformin monotherapy: a randomised trial. Diabetologia 2013;56:2582-92

72 Ferrannini E, Berk A, Hantel S, et al. Long-Term safety and efficacy of empagliflozin, sitagliptin, and metformin: an active-controlled, parallel-group, randomized, 78-week open-label extension study in patients with type 2 diabetes. Diabetes Care 2013;36:4015-21

73 Cherney DZI, Perkins BA, Soleymanlou N, et al. Renal hemodynamic effect of sodium-glucose cotransporter 2 inhibition in patients with type 1 diabetes mellitus. Circulation 2014;129:587-97.

74 Modi A, Agrawal A, Morgan F. Euglycemic diabetic ketoacidosis: a review. Curr Diabetes Rev 2017;13:315-21.

75 MHRA drug safety update: risk of Fournier's gangrene with SGLT2 inhibitors for diabetes. Drug Ther Bull 2019;57:117.

76 Neal B, Perkovic V, Mahaffey KW, et al. Canagliflozin and cardiovascular and rena events in type 2 diabetes. N Engl J Med 2017;377:644-57.

77 Zinman B, Wanner C, Lachin JM, et al. Empagliflozin, cardiovascular outcomes, and mortality in type 2 diabetes. N Engl J Med 2015;373:2117-28. 


\section{Review}

78 Wiviott SD, Raz I, Bonaca MP, et al. Dapagliflozin and cardiovascular outcomes in type 2 diabetes. N Engl J Med 2019;380:347-57.

79 Zelniker TA, Wiviott SD, Raz I, et al. Sglt2 inhibitors for primary and secondary prevention of cardiovascular and renal outcomes in type 2 diabetes: a systematic review and meta-analysis of cardiovascular outcome trials. Lancet 2019;393:31-9.

80 Wanner C, Inzucchi SE, Lachin JM, et al. Empagliflozin and progression of kidney disease in type 2 diabetes. N Engl J Med 2016;375:323-34.

81 Perkovic V, de Zeeuw D, Mahaffey KW, et al. Canagliflozin and renal outcomes in type 2 diabetes: results from the canvas program randomised clinical trials. Lancet Diabetes Endocrinol 2018;6:691-704.

82 Mosenzon O, Wiviott SD, Cahn A, et al. Effects of dapagliflozin on development and progression of kidney disease in patients with type 2 diabetes: an analysis from the DECLARE-TIMI 58 randomised trial. Lancet Diabetes Endocrinol 2019;7:606-17.
83 Perkovic V, Jardine MJ, Neal B, et al. Canagliflozin and renal outcomes in type 2 diabetes and nephropathy. N Eng/ J Med 2019;380:2295-306.

\section{Answers}

1. (d)

2. (e)

3. (c)

4. (d)

5. (d) 